\title{
ORGANIZACJA TERYTORIALNA DIECEZJI CHEŁMSKIEJ I LUBELSKIEJ DO 1805 R.
}

Propozycja powołania do życia diecezji chełmskiej i lubelskiej, będąca przedmiotem dyskusji podczas obrad Sejmu Czteroletniego, zrodziła się na skutek uszczuplenia po I rozbiorze Polski znacznej części terytorium istniejącej od XIV w. diecezji chełmskiej. Jedynym badaczem, który w szczegółach przedstawił organizację terytorialną kościoła łacińskiego na ziemiach trzeciego zaboru austriackiego, obejmującego swoimi granicami także diecezję chełmska i lubelską był ks. Bolesław Kumor ${ }^{1}$. Niniejszy artykuł odwołując się do jego ustaleń delimitacyjnych, będzie stanowił rozszerzoną analizę kwestii i problemów związanych z kształtowaniem się granic przyszłej diecezji lubelskiej, o której niejednokrotnie na łamach prac naukowych pisze się (niestety bez szerszego uzasadnienia), że jest kontynuatorką czy spadkobierczynią diecezji chełmskiej.

Szkic historyczny diecezji chełmskiej od początków jej istnienia przedstawił w cyklu artykułów zamieszczonych w Wiadomościach Diecezjalnych Lubelskich ks. Wincenty Feliks Pawelec ${ }^{2}$, odwołując się niejednokrotnie do pracy ks. Karola Dębińskiego ${ }^{3}$. Liczne rękopiśmienne materiały do dziejów diecezji chełmskiej i lubelskiej zgromadził ks. Jan Ambroży Wadowski, a wykorzystał je pisząc swo-

${ }^{1}$ B. Kumor, Diecezja lubelska (180 lat istnienia), „Wiadomości Diecezjalne Lubelskie” [dalej: WDL], 59 (1985) nr 5-7, s. 234-240; B. Kumor, Granice metropolii i diecezji polskich (966-1939), „Archiwa Biblioteki i Muzea Kościelne” [dalej: ABMK], 20-21 (1970); B. Kumor, Przeniesienie stolicy biskupiej z Chetma do Krasnegostawu (1490), ABMK, 49 (1984) s. 369-380; B. Kumor, Ustrój i organizacja Kościoła polskiego w okresie niewoli narodowej 1772-1918, Kraków 1980.

${ }^{2}$ Artykuł W. Pawelca, Biskupstwo chetmskie (Szkic historyczny), ukazywał się periodycznie w WDL: 15 (1933) nr 8 s. 286-294; nr 9 s. 318-326; nr 10 s. 348-356; 16 (1934) nr 1 s. 11-15; nr 4 s. $134-145$; nr 11 s. $386-400 ; 17$ (1935) nr 1 s. 16-28; nr 2 s. 63-67; nr 3 s. 96-100; nr 6-7 s. 224227.; Uzupełnienia do artykułów: 18 (1936) nr 6 s. 93-96.

${ }^{3}$ K. Dębiński, Chetmska rzymsko-katolicka diecezja obrządku łacińskiego, Lublin 1914. 
ją pracę ks. Walerian Słomka4 . Problematykę Kościoła łacińskiego w ziemi chełmskiej rozwinął w swojej publikacji Włodzimierz Czarnecki ${ }^{5}$.

Obok szczątkowego terytorium diecezji chełmskiej, podległej metropolitalnie archidiecezji lwowskiej, w skład przyszłej diecezji chełmskiej i lubelskiej weszła znaczna część archidiakonatu lubelskiego położonego w diecezji krakowskiej przynależącej do metropolii gnieźnieńskiej. Problematykę struktury terytorialnej archidiakonatu lubelskiego podejmowali w swoich pracach między innymi tacy badacze, jak wspomniany już ks. Bolesław Kumor ${ }^{6}$, Przemysław Szafran ${ }^{7}$, Andrzej Rozwałka ${ }^{8}$ czy Stanisław Litak ${ }^{9}$. Poza wymienionymi dwiema zasadniczymi częściami składowymi terytorium diecezji chełmskiej i lubelskiej, które szerzej omówimy w dalszej części artykułu, w skład analizowanej struktury kościelnej weszły w 1790 r. jeszcze dwa dekanaty z diecezji krakowskiej: dekanat urzędowski z archidiakonatu zawichojskiego oraz dekanat stężycki z dziekanii kieleckiej zwanej również kieleckim dekanatem okręgowym, a w latach 1325-1374 określanej archidiakonatem radomskim ${ }^{10}$

W literaturze przedmiotu bardzo często, poza kwestionowanym już przez nas nazywaniem diecezji lubelskiej kontynuatorką diecezji chełmskiej, pojawia się brak właściwego określenia i wyszczególnienia części składowych diecezji chełmskiej i lubelskiej, natomiast pozostaje się, przy ogólnym stwierdzeniu, że powstała ona $\mathrm{z}$ terytorium diecezji chełmskiej i archidiakonatu lubelskiego, obejmującego województwo lubelskie, ziemię łukowską i stężycką oraz powiat urzędowski ${ }^{11}$. Zatem szczegółowe przedstawienie struktury terytorialnej diecezji chełmskiej i lubelskiej jest zasadniczym przedmiotem niniejszego artykułu. Drugorzędnym jego celem jest wyjaśnienie kwestii kontrowersyjnego nazewnictwa diecezji chełmskiej i lubelskiej oraz tytulatury jej pierwszego biskupa Wojciecha Skarszewskiego.

Pierwszy projekt utworzenia diecezji lubelskiej pojawił się już w połowie XIII w., kiedy to, z polecenia papieża Innocentego IV, zawartego w bulli z 13 VI 1254 r. „Ad audientiam nostram” miała powstać diecezja w Łukowie, której nadrzędnym zadaniem miała być chrystianizacja Jaćwingów. Mimo poparcia tego projek-

${ }^{4}$ W. Słomka, Diecezja chetmsko-lubelska, Lublin 1955 [mps, Biblioteki Metropolitalnego Seminarium Duchownego w Lublinie, sygn. Rkps. 633].

${ }^{5}$ W. Czarnecki, Rozwój sieci parafialnej Kościoła łacińskiego w Ziemi Chetmskiej do początku XVII w., „Roczniki Humanistyczne”, 48 (2000) z. 2 s. 29-87.

${ }^{6}$ Kumor, Dzieje diecezji krakowskiej do roku 1795, t. 4, Kraków 2002.

${ }^{7}$ P. Szafran, Rozwój średniowiecznej sieci parafialnej w Lubelskiem, Lublin 1958.

${ }^{8}$ A. Rozwałka, Sieć osadnicza $w$ archidiakonacie lubelskim $w$ średniowieczu. Studium archeologiczno-historyczne, Lublin 1999.

${ }^{9}$ S. Litak, Formowanie sieci parafialnej w Eukowskiem do końca XVI wieku, Lublin 1965; S. Litak, Kościół łaciński w Rzeczypospolitej około 1772 roku, Lublin 1996.

${ }^{10}$ Biblioteka PAU i PAN w Krakowie, sygn. rękop. 2365, nr mikrof. 36107, J. A. Wadowski, Dzieje diecezji lubelskiej, k. 7-8; Kumor, Dzieje diecezji krakowskiej, s. 85-86.

${ }^{11}$ A. Pawłowska, Diecezja chetmska rzymskokatolicka 1359-1807, „Rocznik Chełmski”, 3 (1997) s. 66-67; Kumor, Granice metropolii, ABMK, 20 (1970) s. 324 [218]; M. T. Zahajkiewicz, Diecezja, jej granice i organizacja terytorialna, w: Dzieje Archidiecezji Lubelskiej (1805-2005), red. M. Zahajkiewicz, Lublin 2005, s. 35. 
tu przez następcę Innocentego IV, Aleksandra IV plan ten prawdopodobnie nie doczekał się realizacji ${ }^{12}$.

$\mathrm{Z}$ inspiracji biskupa chełmskiego Jana Biskupca, dążącego do poszerzenia szczupłego terytorium swojej diecezji powstał projekt utworzenia biskupstwa ze stolicą w samym Lublinie poprzez wydzielenie z diecezji krakowskiej ziemi lubelskiej i przyłączenie jej do diecezji chełmskiej oraz przeniesienie stolicy diecezji z Chełma do Lublina, jak również zmianę nazwy diecezji na lubelską. Swój sprzeciw wobec planów poszerzenia diecezji chełmskiej, które uzyskały już zgodę Stolicy Apostolskiej oraz króla Władysława Jagiełły, wyraził biskup krakowski Zbigniew Oleśnicki, który nie zezwolił na zmniejszenie terytorium własnej diecezji i skłonił papieża Marcina V do zmiany wcześniejszej decyzji, którą papież uzależnił od zgody biskupa i kapituły krakowskiej ${ }^{13}$.

Chronologicznie kolejna propozycja utworzenia biskupstwa ze stolicą w Lublinie została opracowana przez franciszkanina Alberta w 1631 i zakładała utworzenie trzech nowych metropolii w Polsce ( w Krakowie, Wilnie i Kijowie) oraz powstanie 12 nowych diecezji wśród których, miała być również diecezja lubelska.

Czwarty projekt erygowania diecezji lubelskiej zrodził się w 1764 r. na skutek walki politycznej Czartoryskich przeciwko biskupowi krakowskiemu I. K. Sołtykowi, proponujących podział diecezji krakowskiej i wydzielenie z niej diecezji lubelskiej oraz sandomierskiej. Żadnej z powyższych czterech propozycji powołania do życia diecezji lubelskiej nie udało się uskutecznić ${ }^{14}$.

Ustalony na synodzie w 1604 r. przez biskupa Jerzego Zamojskiego podział diecezji chełmskiej na 10 dekanatów (bełski, chełmski, grabowiecki, hrubieszowski, krasnostawski, lubomelski, magierowski, sokalski, turobiński, zamojski), przetrwał bez większych zmian do 1772 r. Jedynie w 1624 r. na synodzie biskup Maciej Łubieński nazwę dekanatu magierowskiego, zamienił na potylicki. ${ }^{15}$

Nieznacznym zmianom uległ natomiast skład parafialny poszczególnych dekanatów. Według danych zgromadzonych przez ks. J. A. Wadowskiego w roku 1604 funkcjonowało w diecezji chełmskiej 59 kościołów parafialnych, w roku 1624 było ich już 70, z kolei przez następne lata liczba ich wzrosła do 81, co zostało odnotowane dla roku 1694 oraz $1717^{16}$.

Powołując się na artykuł ks. Karola Dębińskiego, ks. W. Pawelec przytacza podobne liczby odnoszące się do kościołów parafialnych. W swoim szkicu diecezji chełmskiej podaje, iż w 1604 r. w okresie rządów biskupa Jerzego Zamojskie-

${ }^{12}$ Kumor, Diecezja lubelska, s. 234; W. Pawelec, Biskupstwo Chetmskie. (Szkic historyczny), WDL, 15 (1933) nr 8, s. 286-287; Zahajkiewicz, Diecezja, jej granice, s. 33-34.

${ }^{13}$ Kumor, Diecezja lubelska, s. 234; Pawelec, Biskupstwo Chetmskie. (Szkic historyczny), WDL, 15 (1933) nr 9 s. 319; Zahajkiewicz, Diecezja, jej granice, s. 34-35.

${ }^{14}$ Kumor, Diecezja lubelska, s. 234; Zahajkiewicz, Diecezja, jej granice, s. 35.

${ }^{15}$ Archiwum Archidiecezjalne w Lublinie [dalej: AAL], sygn. Rep 60 I 131, Akta Konsystorza Generalnego Lubelskiego, Urządzenie diecezji Chełmsko-Lubelskiej, później Lubelskiej 17611838, k. 188.; Biblioteka PAU i PAN w Krakowie, J. A. Wadowski, Dzieje dawnej diecezji chetmskiej i jej kościołów, sygn. rękop. 2372, sygn. mikrof. 40752 (700), k. 14-15; Pawelec, Biskupstwo Chetmskie, s. 319; Zahajkiewicz, Diecezja, jej granice, s. 29.

${ }^{16}$ Biblioteka PAU i PAN w Krakowie, J. A. Wadowski, Dzieje dawnej diecezji chełmskiej, k. 15. 
go (1601-1621) liczba kościołów parafialnych w diecezji wynosiła 59, dwadzieścia lat później, gdy biskupem chełmskim został Maciej Łubieński (1621-1627) liczba parafii w 1624 r. równała się 73, z kolei w 1694 r. za biskupa Stanisław Jacka Święcickiego (1677-1696) wzrosła do 81, a w 1717 r., gdy biskupstwo chełmskie objął Krzysztof Jan Szembek (1713-1719) liczba kościołów parafialnych wyniosła $82^{17}$.

Zgodnie z wykazem dekanatów i parafii w diecezji chełmskiej w Rzeczypospolitej Obojga Narodów, sporządzonym przez S. Litaka dla 1772 r., diecezja chełmska położona w tymże roku w granicach metropolii lwowskiej, dzieliła się na 10 dekanatów obejmujących 84 kościoły parafialne, nie licząc kościołów filialnych oraz wszelkiego rodzaju kaplic publicznych. Wśród wymienionych dekanatów znalazły się: dekanat Bełz (7 parafii), dekanat Chełm - 12 parafii, Grabowiec (9 parafii), Hrubieszów (5 parafii), Krasnystaw (9 parafii), Luboml (9 parafii), Potylicz (9 parafii), Sokal (7 parafii), Turobin (7 parafii) oraz Zamość (10 parafii) ${ }^{18}$.

W tymże roku obszar powstałego w XII w. archidiakonatu lubelskiego, leżącego w granicach diecezji krakowskiej, archidiecezji gnieźnieńskiej, obejmował 5 rozległych dekanatów, na obszarze których, funkcjonowało 81 kościołów parafialnych, 1 kolegiata oraz 45 filii i kaplic mszalnych ${ }^{19}$. Do dekanatów tych należały: dekanat Chodel (21 parafii), dekanat Kazimierz Dolny (14 parafii), dekanat Łuków (14 parafii), Parczew (22 parafie), Solec (10 parafii).$^{20}$ Można zauważyć, iż liczba kościołów parafialnych w diecezji chełmskiej w 1772 była porównywalna do liczby parafii w archidiakonacie lubelskim w diecezji krakowskiej, jednakże liczba dekanatów w tym ostatnim była o połowę mniejsza, od liczby dekanatów w diecezji chełmskiej. Natomiast ilość parafii w dekanatach diecezji chełmskiej wahająca się od 5 do 12 była o połowę niższa od liczby parafii w dekanatach archidiakonatu lubelskiego, których obszar organizowało od 10 do 22 parafii. Przyczyn rozbieżności w liczbach parafii i dekanatów zarówno diecezji chełmskiej, jak i archidiakonatu lubelskiego należy szukać w rozwoju sieci osadniczej, a co za tym idzie w stopniu zagęszczenia sieci parafialnej na tych terenach. Według P. Szafrana badającego rozwój średniowiecznej sieci parafialnej w Lubelskiem, w wielu przypadkach tworzenie nowych parafii zbiegało się w czasie z powstawaniem nowych osad lub powiększaniem starych. Toteż proces rozwoju i zagęszczania sieci parafialnej na przełomie XIV i XV w. na obszarze Lubelszczyzny zbiegł się $\mathrm{w}$ czasie $\mathrm{z}$ jej rozwojem społeczno-gospodarczym ${ }^{21}$. Pogląd ten w odniesieniu do organizowania się sieci archidiakonatów w średniowieczu podziela A. Rozwałka, który zgadza się z tezą, iż na terenie Europy Zachodniej diecezje, w których archidiakonaty powstawały prawie równocześnie leżały na obszarach o największym zagęszczeniu ludności. ${ }^{22}$

${ }^{17}$ Pawelec, Biskupstwo Chetmskie, s. 319.

${ }^{18}$ Litak, Atlas Kościoła łacińskiego w Rzeczypospolitej Obojga Narodów w XVIII wieku, Lublin 2006, s. 330-333.

${ }^{19}$ Kumor, Dzieje diecezji krakowskiej, s. 63.

${ }^{20}$ Tamże, s. 254-257.

${ }^{21}$ Szafran, Rozwój średniowiecznej sieci parafialnej, s. 90, 97.

${ }^{22}$ Rozwałka, Sieć osadnicza, s. 22-23. 
Znacznie bardziej zagęszczona sieć parafialna w archidiakonacie lubelskim w porównaniu z siecią parafii w diecezji chełmskiej, jest wynikiem jej rozwoju już we wczesnym średniowieczu. Przy czym na terytoriach wschodnich Rzeczypospolitej rozwijała się ona znacznie później, bo dopiero w XVII i XVIII w. Ponadto na wschodnich terytoriach Rzeczypospolitej gdzie występowała większa liczba obrządków i wyznań chrześcijańskich, sieć łacińskich kościołów parafialnych była rzadsza $\mathrm{w}$ porównaniu $\mathrm{z}$ ziemiami etnicznie polskimi. ${ }^{23}$ Dodatkowo diecezja chełmska należała do najuboższych w Polsce, głównie z powodu złej sytuacji demograficznej oraz wyznaniowej. Według W. Czarneckiego w XVIII w. na 15 diecezji funkcjonujących w Polsce, diecezja chełmska pod względem prestiżu i uposażeń zajmowała 11 miejsce. ${ }^{24}$

Podział diecezji chełmskiej na 10 dekanatów za rządów biskupa Jerzego Zamojskiego w 1604 r. (ze zamianą nazwy dekanatu magierowskiego na potylicki w 1624 r.), nie uległ przekształceniu, podczas synodu zwołanego do Krasnegostawu przez biskupa Krzysztofa Jana Szembeka w 1717 r. i przetrwał bez żadnych modyfikacji do roku $1772^{25}$. Porównując skład kościołów parafialnych poszczególnych dekanatów w 1717 r. z liczbą tworzących je w 1772 r. parafii, możemy stwierdzić, że zmiany te były niewielkie i dotyczyły między innymi dekanatu chełmskiego, w którym w 1717 r. w porównaniu z 1772 r. nie odnotowano parafii w Dorohusku, bowiem powstała ona dopiero w drugiej połowie XVIII w. W dekanacie lubomelskim w 1717 r. brak parafii Ostrówki, w dekanacie turobińskim nie odnotowano dla tegoż roku parafii w Puszczy Solskiej, zaś w dekanacie zamojskim nie odnajdujemy w spisie z 1717 r. parafii Górecko oraz Krasnobród. Odnotowana w $1717 \mathrm{r}$. w pozostałych dekanatach diecezji chełmskiej liczba kościołów parafialnych jest porównywalna z ich wykazem z roku 1772. Przy niezmienionym składzie w porównaniu z 1717 r. pozostało przez kolejnych 55 lat sześć następujących dekanatów diecezji chełmskiej: bełski, grabowiecki, hrubieszowski, krasnostawski, potylicki i sokalski ${ }^{26}$.

Po pierwszym rozbiorze Polski większa część diecezji chełmskiej wraz z Zamościem (51 parafii), a także archidiecezja lwowska, diecezja przemyska, cała zawiślańska część diecezji krakowskiej oraz skrawek diecezji kamienieckiej i łuckiej znalazły się pod okupacją austriacką. Spośród 10 dekanatów diecezji chełmskiej, aż siedem odciętych zostało kordonem zaboru austriackiego (Bełz, Grabowiec, Hrubieszów, Potylicz, Sokal, Zamość i częściowo Krasnystaw), a w 1782 r. z polecenia cesarza Józefa II zostały one włączone do diecezji przemyskiej. Przy okrojonej diecezji chełmskiej położonej w Polsce, poza obszarem zaborowym po 1772 r., pozostały w całości trzy dekanaty: chełmski z 14 parafiami, lubomelski

${ }^{23}$ Litak, Atlas Kościoła tacińskiego, s. 33-35.

${ }^{24}$ Czarnecki, Rozwój sieci parafialnej, s. 53 (przypis 209).

${ }^{25}$ Biblioteka PAN i PAU w Krakowie, Cypryana Walewskiego: Notaty historyczne do opisu dyecezyi lubelskiej. (drugi tytut: Cyprian Walewski, Opis historyczny Dyecezyi Lubelskiej. Notatki), sygn. rekop. 757, sygn. mikrof. 30829 (446), k. 13; Pawelec, Biskupstwo Chetmskie. (Szkic historyczny), WDL 15 (1933) nr 9 s. 319-320.

${ }^{26}$ Słomka, Diecezja chetmsko-lubelska, s. 46-47; Litak, Atlas Kościoła łacińskiego, s. 330-333; Pawelec, Biskupstwo Chetmskie, s. 319-320. 
z 10 parafiami oraz turobiński z 6 parafiami i częściowo dekanat krasnostawski z 5 parafiami oraz z dekanatu hrubieszowskiego parafia Dubienka ${ }^{27}$. W 1788 r. w granicach dekanatu chełmskiego funkcjonowało 12 parafii (Chełm, Czułczyce, Dorohusk, Kumów, Olchowiec, Orchówek, Pawłów, Sawin, Sosnowica, Świerże, Uhrusk i Wereszczyn), z kolei uszczuplony obszar dekanatu krasnostawskiego został połączony z dekanatem turobińskim, na skutek czego, powstał składający się z 14 parafii jeden dekanat pod nazwą krasnostawskiego i turobińskiego, później krasnostawskiego (Biłgoraj, Chłaniów, Czernięcin, Gorzków, Krasnystaw, Łopiennik, Płonka, Puszcza Solska, Siennica, Surhów, Tarnogóra, Turobin, Wojsławice, Żółkiewka). W granicach trzeciego dekanatu uszczuplonej diecezji chełmskiej - lubomelskiego, znajdowało się w 1788 r. 10 następujących parafii: Dubienka, Korytnica, Kamień Koszyrski, Luboml, Maciejów, Opalin, Ostrówki, Przewały, Ratno, Terebejki ${ }^{28}$. Łącznie $w$ granicach trzech dekanatów diecezji chełmskiej funkcjonowało tylko 36 parafii.

W tymże roku 7 października aktem konfederacyjnym otwarto obrady Sejmu Czteroletniego, którego pierwszoplanowym posunięciem było zwiększenie liczby wojska do stu tysięcy oraz wskazanie funduszu na jego utrzymanie. Część posłów widziała rozwiązanie tego problemu w konfiskacie dóbr wakującego biskupstwa krakowskiego i przekazaniu ich na fundusz dla wojska. Drugim sposobem podniesienia finansów armii miało być opodatkowanie duchowieństwa. Postulatorami takiego sposobu zaradzenia problemom braku funduszy na utrzymanie wojska byli między innymi Wojciech Suchodolski poseł chełmski oraz kasztelan łukowski Jezierski. Propozycję tą W. Suchodolski przedłożył przed obrady Sejmu w styczniu 1789 r., jednakże miała ona wielu oponentów, zarówno wśród duchownych, jak i świeckich, do których zaliczali się także marszałek sejmu Stanisław Małachowski oraz sam król. Pomimo głosów sprzeciwu sprawa dóbr biskupstwa krakowskiego powracała na kanwy dyskusji przez blisko pół roku. Propozycja podziału tych dóbr pomiędzy ubogie biskupstwa, do których obok kamienieckiego, smoleńskiego i inflanckiego, zaliczało się także biskupstwo chełmskie była bliższa realizacji. Podniesiony przez króla głos, aby z rozległego biskupstwa krakowskiego wydzielić część i przeznaczyć ją na zasilenie uboższych diecezji, w tym także diecezji chełmskiej został zatwierdzony. Ustawą z dnia 31 lipca 1789 r. przyjęto projekt nowej organizacji diecezji w Polsce poprzez zabór dóbr biskupstwa krakowskiego, rozwiązując tym samym, wielokrotnie podnoszony przez biskupów chełmskich problem powiększenia terytorium diecezji chełmskiej, poprzez wydzielenie z diecezji krakowskiej przewarzającej części terytorium archidiakonatu lubelskiego ${ }^{29}$. W. Słomka w swojej pracy przeciwstawia się teorii ks. W. Pawelca, jakoby przyłączenie archidiakonatu lubelskiego do diecezji chełmskiej nastąpiło na prośbę ówczesnego biskupa chełmskiego Macieja Garnysza. Zdaniem W. Słomki popularność zarówno wśród duchownych, jak i świeckich, biskupa Garnysza, pełniącego na Sejmie liczne funkcje, zwracała uwagę uczestników

${ }^{27}$ Kumor, Diecezja lubelska, s. 235; Kumor, Granice metropolii, s. 322 [216]-323 [217]; Kumor, Ustrój i organizacja, s. 153

${ }^{28}$ Directorium Officii Divini pro Dioecesi Hetmensi in Annum Domini 1789.

${ }^{29}$ Słomka, Diecezja chetmsko-lubelska, s. 21-26. 
obrad sejmowych na ubóstwo samego biskupstwa chełmskiego, a ponadto sam biskup Garnysz zbyt zajęty był sprawami państwowymi, aby podejmować działania w kierunku przeforsowania projektu rozszerzenia granic swojej diecezji. Ponadto przekazanie części dóbr biskupstwa krakowskiego na rzecz uboższych diecezji leżało w interesie samego duchowieństwa, a także świeckich biorących te dobra w obronę, przed postulatami przekazania ich na rzecz skarbu państwa i obrócenia na cele świeckie, $\mathrm{w}$ tym na fundusz dla wojska ${ }^{30}$. Dlatego też projekt ten powstał na „konferencjach deputacji od spraw duchownych z nuncjuszem”. Ponadto jak pisze W. Słomka „Ks. Biskup Garnysz, chociażby mu bardzo zależało na przyłączeniu archidiakonatu lubelskiego do swojej diecezji, to jednak widząc bieg spraw nie potrzebował sam występować i afiszować się z tym, gdyż jeszcze gorliwiej wyręczali go w tym obrońcy dóbr kościelnych, konkretnie biskupstwa krakowskiego i to zarówno duchowni, jak i świeccy. Obrońcy ci widzieli ostatnią deskę ratunku tych dóbr przed zabraniem ich na rzeczy świeckie, w przydzieleniu ich biskupstwom ubogim." Wynika stąd, że sami biskup chełmski nie był twórcą projektu, natomiast tylko przesłał Stolicy Apostolskiej uchwałę sejmową z dnia 11 czerwca 1790 r. z prośbą o jej zatwierdzenie ${ }^{31}$. Papież Pius VI dokonał jej zatwierdzenia dekretem Kongregacji Konsystorialnej Quum Reverendissimus z dnia 22 lipca 1790 r. Dekret ten zdaniem ks. B. Kumora oraz odwołującego się do jego ustaleń ks. M. T. Zahajkiewicza, nie zatwierdzał zmiany nazwy diecezji. Dla poparcia tego stwierdzenia obydwaj badacze dziejów diecezji lubelskiej powołują się na zapis konstytucji sejmowej nr 151 zawarty w IX tomie „Volumina legum”, jednakże nie odnajdujemy w nim wzmianki odnoszącej się do nazwy samej diecezji, a jedynie do tytulatury biskupa. Fragment tego zapisu brzmi następująco: „(...) W uskutecznieniu umówionego z stolicą ś. apostolską dyecezyów podziału, ponieważ część dyecezyi Krakowskiey, to iest: województwo Lubelskie, ziemia Łukowska, powiat Urzędowski, i ziemia Stężycka biskupowi Chełmskiemu, do tey szczupłej dyecezyi, którą on dziś posiada przydaie się; przeto przez wzgląd na powiększenie tegoż biskupa Chełmskiego (który odtąd tytuł biskupa Lubelskiego i Chełmskiego razem brać będzie) obowiązki, skłaniaiąc się do nieodwłocznego opatrzenia onegoż, deklarujemy: (...)"32.

Ponadto, jak konstatuje dalej za ks. Kumorem ks. M. T. Zahajkiewicz, biskup Garnysz nie traktował diecezji chełmskiej powiększonej o część diecezji krakowskiej (w tym o znaczną część archidiakonatu lubelskiego) jako diecezji chełmskolubelskiej, lecz uznawał jej nowy obszar jako jedną diecezję chełmską, której terytorium uległo poszerzeniu o anektowaną część biskupstwa krakowskiego. Tenże argument, jak również brzmienie dekretu erygującego diecezję lubelską w 1805 r., jest dla ks. Zahajkiewicza wystarczającym dowodem na nieistnienie po $1790 \mathrm{r}$. diecezji chełmsko lubelskiej. Jednakże dla nas argumentacja ta nie jest wystarczająca, aby zgodzić się z powyższym stwierdzeniem. Po pierwsze dlatego, że jak sam ks. Zahajkiewicz zauważa już na początku października 1790 r. zmarł biskup

30 Tamże, s. 29.

31 Tamże, s. 30-31.

${ }^{32}$ Volumina legum. Prawa, konstytucye y przywileie Królestwa Polskiego, Wielkiego Księstwa Litewskiego y wszystkich prowincyi należacych, t. 9, Kraków 1889, s. 175. 
Garnysz, zaś jego następca biskup Wojciech Skarszewski oficjalnie zaczął tytułować się biskupem chełmskim i lubelskim. Zatem fakt, iż biskup Garnysz, sprawując swe rządy nad nowym obszarem diecezji chełmskiej przez zaledwie dwa i pół miesiąca nie tytułował się biskupem chełmskim i lubelskim, nie oznacza, że jego następca piastujący ten urząd przez kilkanaście lat nie zmienił swojej tytulatury. Jak już wspomnieliśmy, biskup Skarszewski od pierwszych dni swojej posługi w diecezji chełmskiej i lubelskiej tytułował się biskupem chełmskim i lubelskim, co więcej, w aktach protokołów Konsystorza lubelskiego za lata 1790-1794, biskup Wojciech Skarszewski tytułowany jest biskupem chełmskim, lubelskim i bełskim, biskup Jan Kanty Lenczowski określany jest mianem biskupa sufragana lubelskiego, biskupa abderytańskiego, kustosza kościoła katedralnego chełmskiego, zaś sama diecezja utworzona w 1790 r., zwana jest w aktach protokołów z 1791 r. diecezją chełmską lubelską i bełskąa

Ingrossowany dokument rozgraniczenia mocą bulli papieskiej diecezji krakowskiej i przyłączenia części jej terytorium do diecezji chełmskiej, zamieszczony w aktach protokołów Kurii biskupiej chełmskiej, opublikowany został w Schematyźmie diecezji lubelskiej na rok 1875. Zapis tytulatury biskupa Wojciecha Leszczyca Skarszewskiego w tymże dokumencie z 1791 r. brzmi (...) „Adalberti Leszczyc Skarszewski Dei et Aplicea Sedis Gratia Epi Hełmensis et Lublinensis" $(\ldots)^{34}$. Nazwa diecezji zawarta $\mathrm{w}$ tytule pierwszego wydanego po zmianach granic diecezji chełmskiej Directorium na rok 1791 składa się z trzech członów i figuruje jako diecezja chełmska, lubelska i bełska. To samo określenie utrzymuje się w tytule Directorium na rok 1792 oraz na rok 1793. Przy czym Directorium na rok 1793 zawiera w sobie pierwszy po zmianach reorganizacyjnych spis parafii oraz duchowieństwa ujęty w ramach ustanowionych przez biskupa Skarszewskiego dwóch oficjałatów: chełmskiego i lubelskiego. Brak natomiast w tymże Directorium, a także i w następnych rocznikach, przywróconego do życia w lutym 1791 r. oficjałatu łukowskiego pod jurysdykcją którego znalazły się dwa dekanaty: łukowski i stężycki ${ }^{35}$. W granicach oficjałatu generalnego chełmskiego znalazła się ta część diecezji chełmskiej, która obejmowała tereny poza kordonem zaboru austriackiego. Oficjałat generalny lubelski obejmował tę część diecezji, która została przyłączona w 1790 r., bez dekanatu łukowskiego i stężyckiego dla których dekretem z 5 lutego $1791 \mathrm{r}$. został utworzony oficjałat łukowski ${ }^{36}$. Według Directorium Officii Divini pro Dioecesi Hetmensi et Lublinensi in Annum Domini 1794, w oficjałacie chełmskim funkcjonowały trzy dekanaty (chełmski, lubomelski oraz krasnostawski i turobiński, przy czym te dwa ostatnie występowały, jako jeden o podwójnej nazwie) liczące łącznie 36 parafii w tym 1 filialną.

${ }^{33}$ AAL, sygn. Rep 60 A 209, Akta Konsystorza Generalnego Lubelskiego, Protokollon actorum Consistrii Lublinensis ab an 1790 ad 1794, k. 13v-15.

${ }^{34}$ Catalogus universi cleri saecularis et regularis Dioecesis Lublinensis Anno Domini 1875, Lublin 1874, s. III-IV (Documentum I ).

${ }^{35}$ Directorium Officii Divini pro Dioecesi Lublinensi, Hetmensi et Belzensi in Annum Domini 1791; Directorium Officii Divini pro Dioecesi Hetmensi Lublinensi et Betżensi in Annum Domini 1792; Directorium Officii Divini pro Dioecesi Hetmensi Lublinensi et Betżensi in Annum Domini 1793.

${ }^{36}$ Słomka, Diecezja chetmsko-lubelska, s. 49-50. 
W skład dekanatu chełmskiego wchodziło wówczas 12 parafii (Chełm, Czułczyce, Dorohusk, Kumów, Olchowiec, Orchówek, Pawłów, Sawin, Sosnowica, Świerże, Uhrusk, Wereszczyn); dekanat krasnostawski i turobiński tworzyło 14 parafii w tym jedna filialna (Biłgoraj, Chłaniów, Czernięcin filia, Gorzków, Krasnystaw, Łopiennik, Płonka, Puszcza Solska, Siennica, Surhów, Tarnogóra, Turobin, Wojsławice, Żółkiewka); zaś w dekanacie lubomelskim znajdowłało się 10 parafii (Czerniawka Dubienka, Korytnica, Kamień Koszyrski, Luboml, Maciejów, Opalin, Ostrówki, Przewały, Ratno). W porównaniu ze składem parafialnym dekanatu lubomelskiego w 1788 i 1792 r. zanikła parafia Terebejki, natomiast od 1793 r. (Directorium na rok 1794) w dekanacie tym pojawiła się parafia Czerniawka, która funkcjonowała w nim do 1795 r. po czym również zanikła. Ponadto w tymże roku znajdująca się w dekanacie lubomelskim parafia Dubienka, została włączona do dekanatu chełmskiego. W dalszej kolejności Directorium na rok 1794 obok trzech dekanatów z oficjałatu chełmskiego, wymienia 6 dekanatów funkcjonujących w 1793 r, w oficjałacie lubelskim, z tym, że dekanaty łukowski i stężycki wykazane są, nie w granicach oficjałatu łukowskiego, o którym nie ma wzmianki w Directoriach za lata 1790-1807, tylko w obrębie wspomnianego oficjałatu lubelskiego. Zatem w 1793 r. tenże oficjałat miał pod swoją jurysdykcją 6 dekanatów. Od 1797 r. liczba ta zwiększyła się o jeden dekanat, na skutek wydzielenia części dekanatu chodelskiego (10 parafii w tym 2 filii) oraz 2 parafii z dekanatu parczewskiego (Fajsławice oraz Piaski) i utworzenia z nich dekanatu lubelskiego. W skład 6 dekanatów oficjałatu generalnego lubelskiego (chodelskiego, kazimierskiego, łukowskiego, parczewskiego, stężyckiego oraz urzędowskiego) weszło w 1793 r. 118 parafii, w tym 13 filii oraz jedna kaplica publiczna. Każdy z tych dekanatów posiadał następującą liczbę parafii: dekanat chodelski tworzyło 25 parafii wraz z 4 filiami (Abramowice, Bełżyce, Boby, Boiska, Bychawa, Bychawka, Chodel, Czerniejów, Częstoborowice, Czwartek, Kiełczewice, Kluczkowice filia, Konopnica, Krężnica filia, Krzczonów, Lublin, Matczyn, Niedrzwica, Opole, Piotrawin, Ratoszyn filia, Wilkołaz, Wojciechów filia, Zakrzówek, Zemborzyce); w dekanacie kazimierskim odnotowano 13 parafii w tym jedną filialną (Bochotnica, Garbów, Gołąb, Karczmiska filia, Kazimierz, Klementowice, Końskowola, Kurów, Markuszów, Wąwolnica, Wilków, Włostowice, Żyrzyn); dekanat łukowski składał się z 15 parafii w tym jednej filialnej (Adamów, Domanice, Kąkolewnica filia, Łuków, Pruszyn, Radoryż, Radzyń, Serokomla, Siedlce, Stanin, Trzebieszów, Tuchowicz, Ulan, Wojcieszków, Zbuczyn); w granicach dekanatu parczewskiego funkcjonowały 24 parafie, w tym jedna filialna i jedna kaplica publiczna (Baranów, Biskupice, Bystrzyca, Czemierniki, Dys, Fajsławice, Firlej filia, Kamionka, Kijany, Kock, Krasienin, Lubartów, Łańcuchów, Łaszczów kap pub, Łęczna, Łysobyki, Mełgiew, Michów, Ostrów, Parczów, Piaski, Puchaczów, Rudno, Serniki); w dekanacie stężyckim znajdowało się 17 parafii (Bobrowniki, Brzeziny, Drążgów, Gończyce, Górzno, Kłoczew, Korytnica, Maciejowice, Nowodwór, Okrzeja, Pawłowice, Ryki, Stężyca, Wargocin, Wilczyska, Żabianka, Żelechów), z kolei dekanat urzędowski obejmował 24 kościoły parafialne w tym 6 filialnych (Annopol filia, Batorz, Biała, Blinów filia, Borów, Boża Wola filia, Dzierzkowice, Frampol filia, Goraj, Gościeradów, Kraśnik, Księ- 
żomierz filia, Modliborzyce, Popkowice, Potok, Prawno, Radzięcin, Rybitwy, Rzeczyca filia, Świeciechów, Targowisko, Urzędów, Wysokie, Zaklików) ${ }^{37}$.

Utworzona podczas Sejmu Wielkiego oraz usankcjonowana dekretem papieskim z 1790 r. diecezja chełmska i lubelska powstała z terenów leżących w granicach dwóch metropolii: lwowskiej oraz gnieźnieńskiej. Z metropolii lwowskiej pochodziła ta część diecezji chełmskiej, która w 1790 r. pozostając przy Polsce, jednocześnie znalazła się poza granicą zaboru austriackiego. W jej skład wchodziły trzy dekanaty o rzadkiej sieci parafialnej: chełmski, krasnostawski i turobiński oraz lubomelski, o łącznej liczbie 36 parafii.

Diecezja krakowska podległa metropolii gnieźnieńskiej utraciła ogółem na rzecz diecezji chełmskiej i lubelskiej 118 parafii położonych w granicach trzech mniejszych jednostek administracji kościelnej, a mianowicie: archidiakonatu lubelskiego (4 dekanaty i 77 parafii); dziekanii kieleckiej (1 dekanat i 17 parafii) oraz archidiakonatu zawichojskiego (1 dekanat i 24 parafie).

Porównując sieć dekanalną i parafialną archidiakonatu lubelskiego w 1772 i 1790 r. możemy zauważyć, że spośród pięciu tworzących go w 1772 r. dekanatów do diecezji chełmskiej i lubelskiej zostały przyłączone cztery: chodelski, kazimierski, łukowski oraz parczewski, z wyłączeniem dekanatu soleckiego. A ponadto $w$ granicach nowej diecezji nie znalazły się dwie parafie $z$ dekanatu kazimierskiego, a mianowicie Jaroszyn oraz Regów. Podobnie z dekanatu urzędowskiego, archidiakonatu zawichojskiego nie zostały wcielone do diecezji chełmskiej i lubelskiej trzy parafie: Pniów, Wrzawy oraz Radomyśl. Z kolei parafia Samogoszcz z dziekanii kieleckiej dekanatu stężyckiego pojawia się w Directoriach diecezji chelmskiej i lubelskiej dopiero od $1796 \mathrm{r}^{38}$

Analogicznie porównując liczbę dekanatów oraz parafii diecezji chełmskiej w 1772 i po jej rozpadzie na skutek I rozbioru Polski, zauważamy, ze spośród 10 dekanatów tejże diecezji z 1772 r., w skład diecezji chełmskiej i lubelskiej w 1790 r. weszły prawie w całości trzy dekanaty: chełmski, lubomelski i turobiński (bez parafii Mokrelipie) oraz część krasnostawskiego bez trzech parafii Bończa, Skierbieszów oraz Uchanie. Dwa ostatnie dekanaty utworzyły po 1790 r. jeden dekanat pod nazwą krasnostawskiego i turobińskiego (później krasnostawskiego) ${ }^{39}$. Pozostałych 7 dekanatów diecezji chełmskiej (Bełz, Grabowiec, Hrubieszów, Potylicz, Sokal, Zamość i częściowo Krasnystaw), jak już wyżej wspomnieliśmy, znalazło się na obszarze zaboru austriackiego i zostało przyłączonych do diecezji przemyskiej. Poszczególne części składowe diecezji chełmskiej i lubelskiej ujmuje tabela nr 1 oraz odpowiadający jej wykres nr 1.

${ }^{37}$ Directorium Officii Divini pro Dioecesi Hetmensi et Lublinensi in Annum Domini 1794.

${ }^{38}$ Directorium Officii Divini pro Dioecesi Hetmensi et Lublinensi in Annum Christi Bissextilem 1796.

${ }^{39}$ Directorium Officii ... in Annum Domini 1793. 
Tabela 1. Części składowe terytorium diecezji chełmskiej i lubelskiej około $1790 \mathrm{r}$.

\begin{tabular}{|l|l|l|l|l|l|}
\hline & & &
\end{tabular}

Źródło: Directorium Officii Divini pro Dioecesi Hetmensi, Lublinensi et Betżensi in Annum Domini 1793.; S. Litak, Atlas Kościoła łacińskiego w Rzeczypospolitej Obojga Narodów w XVIII wieku, Lublin 2006.

Wykres 1. Części skła dowe diecezji chełmskiej i lubelskiej w 1790 r.

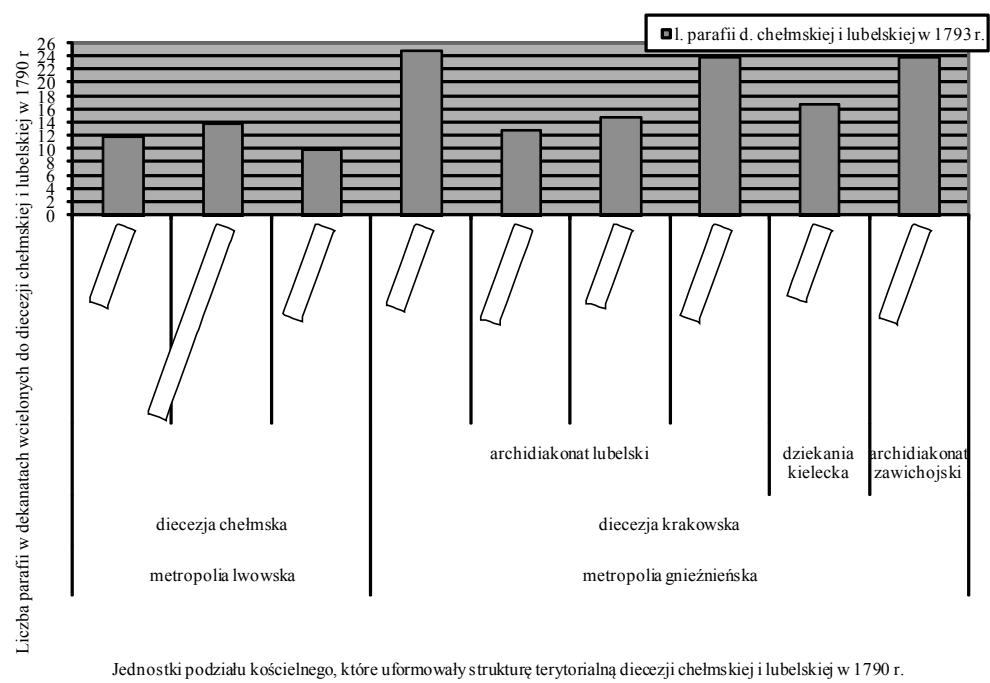


Diecezja chełmska i lubelska przetrwała w ustalonych w 1790 r. granicach zaledwie 5 lat, czego przyczyną po raz kolejny stała się rzeczywistość rozbiorowa. Traktat rozbiorowy zawarty pomiędzy Austrią i Rosją dnia 3 stycznia 1795 r. spowodował między innymi anektowanie przez Austrię nowych terenów, obejmujących pod względem kościelnym całą diecezję krakowską oprócz trzech dekanatów podległych panowaniu pruskiemu, a ponadto Austria zagarnęła całą diecezję chełmską i lubelską oprócz dekanatu lubomelskiego, pozostałego po stronie zaboru rosyjskiego, jak również anektowała 6 dekanatów z archidiakonatu kurzelowskiego archidiecezji gnieźnieńskiej; oraz z tejże archidiecezji część archidiakonatu warszawskiego z diecezji poznańskiej oraz część diecezji płockiej, a także z archidiecezji lwowskiej część diecezji łuckiej. $Z$ terenów trzeciego zaboru austriackiegozostała utworzona nowa prowincja zwana GalicjąZachodniąze stolicą w Krakowie $^{40}$. Dyrektorium wiedeńskie dekretem z 14 marca 1796 r. zapowiedziało uporządkowanie organizacji kościelnej na terenach anektowanych, zgodnie z przyjętą zasadą, aby żaden z biskupów zakordonowanych, nie mógł pełnić jurysdykcji kościelnej nad wiernymi innego zaboru. Biskupi na polecenie władz zaborczych przystąpili do tworzenia oficjałatów i wikariatów generalnych dla tych części diecezji, których stolice znalazły się poza granicami zaboru austriackiego ${ }^{41}$.

Dla odłączonego od diecezji chełmskiej i lubelskiej i wcielonego do Rosji dekanatu lubomelskiego (wraz z 10 parafiami) biskup Wojciech Skarszewski 28 września 1795 r. erygował oficjałat ratneński, nad którym jurysdykcję przekazał ks. Mikołajowi Faliszewskiemu, kantorowi kaptuły łuckiej, a niespełna rok później powierzył ją biskupowi kijowskiemu Kasprowi Cieciszowskiemu. Dekretem z dnia 8 sierpnia 1798 r. delegat apostolski Wawrzyniec Litta włączył oficjałat ratneński do diecezji łuckiej ${ }^{42}$. Podobny oficjałat dla austriackiej części diecezji poznańskiej (z 37 parafiami) erygował w Garwolinie przed 20 IV 1799 r. biskup poznański Ignacy Raczyński, przekazując w nim jurysdykcję kościelną ks. F. Mike, a nieco później pod koniec 1799 r. na żądanie władz austriackich przekazał ją ordynariuszowi krakowskiemu F. Turskiemu, a po jego śmierci (31 III 1800) administratorowi tejże diecezji J. Olechowskiemu. Kolejny oficjałat generalny został utworzony 8 maja 1798 r. w Kurzelowie przez arcybiskupa Ignacego Krasickiego. Objął on 84 parafie archidiecezji gnieźnieńskiej, które po trzecim rozbiorze znalazły się pod panowaniem austriackim, powierzając nad nimi jurysdykcję kanonikowi kurzelowskiemu ks. Franciszkowi Janowi Zdziechowiczowi. Trzy lata później po śmierci arcybiskupa Krasickiego nuncjatura wiedeńska z nakazu władz zaborczych, dekretem z 8 kwietnia 1801 r. przekazała jurysdykcję w oficjałacie kurzelowskim ordynariuszowi krakowskiemu.

${ }^{40}$ Kumor, Ustrój i organizacja, s. 153-154; tenże, Granice metropolii, ABMK 20 (1970) s. 325 [219]; tenże., Diecezja lubelska, s. 236; tenże., Organizacja terytorialna diecezji kieleckiej, „Nasza Przeszłość", 17 (1963) s. 188 [2]; Zahajkiewicz, Diecezja, jej granice, s.36.

${ }^{41}$ Kumor, Ustrój i organizacja, s. 162; T. Mencel, Galicja Zachodnia (1795-1809). Studium z dziejów ziem polskich zaboru austriackiego po III rozbiorze, Lublin 1976, s. 165.

${ }^{42}$ Kumor, Granice metropolii, ABMK 20 (1970) s. 325 [219]; tenże., Organizacja terytorialna, s. 188 [2]-189 [3]. 
Oficjałat generalny powołał dnia 19 października 1797 r. biskup płocki K. Szembek, dla tej części swojej diecezji w rejonie Stanisławowa, Radzymina i Kamieńczyka (19 parafii), która znalazła się w Galicji Zachodniej, jednocześnie urząd oficjała i wikariusza generalnego powierzając ks. Ignacemu Obrębskiemu dziekanowi kamieńczykowskiemu.

Dla austriackiej części diecezji łuckiej obejmującej 47 parafii w rejonie Węgrowa, Międzyrzeca i Janowa Podlaskiego oraz dla części pruskiej tejże diecezji metropolita gnieźnieński Ignacy Krasicki dnia 25 lipca 1796 r. wyznaczył na administratora ks. Tomasza Halyburtona z Białej Podlaskiej, co spowodowało powstanie oddzielnej administracji diecezji łuckiej w Galicji Zachodniej ${ }^{43}$.

Podsumowując, diecezja chełmska zwana od 1790 r. chełmską i lubelską składała się z 9 dekanatów liczących w sumie 154 parafie (w tym 14 filii oraz 1 kaplica publiczna) $)^{44}$.Odłączenie od diecezji chełmskiej i lubelskiej po trzecim rozbiorze Polski dekanatu lubomelskiego stało się przyczyną zmiany granic diecezji chełmskiej i lubelskiej, która utraciła na wschodzie 10 parafii. W okresie od 1795 do 1805 r. w strukturach terytorialnych diecezji chełmskiej i lubelskiej zaszło jeszcze kilka modyfikacji. Już w 19 kwietnia 1797 z części dekanatu chodelskiego (12 parafii) oraz dwóch parafii dekanatu parczewskiego (Fajsławice oraz Piaski) utworzono dekanat lubelski ${ }^{45}$, a tym samym do 8 dekanatów pozostających w jej granicach od 1795 r. (chełmskiego, krasnostawskiego i turobińskiego (krasnostawskiego), chodelskiego, parczewskiego, kazimierskiego, urzędowskiego, łukowskiego oraz stężyckiego) dodano kolejny lubelski. Zarządzeniem z dnia 25 listopada $1801 \mathrm{r}$. z dekanatu urzędowskiego został wydzielony dekanat zaklikowski, zaś z części dekanatu parczewskiego i kazimierskiego utworzono dekanat kurowski, znosząc jednocześnie dekanat kazimierski oraz wcielając pozostałe jego parafie do dekanatu chodelskiego ${ }^{46}$. Po zniesieniu dekanatu kazimierskiego oraz utworzeniu dekanatu kurowskiego i zaklikowskiego, pierwszy z nich znalazł się w cyrkule lubelskim, natomiast dekanat zaklikowski został włączony do cyrkułu józefowskiego.

Tym samym liczba dekanatów diecezji chełmskiej i lubelskiej od roku 1797 wzrosła o 3 i jednocześnie zmalała o jeden dając w ostateczności od 1802 r. bilans 10 dekanatów: chełmski, krasnostawski, chodelski, parczewski, kurowski, lubelski, łukowski, stężycki, urzędowskiego, zaklikowski ${ }^{47}$.

${ }^{43}$ Kumor, Ustrój i organizacja Kościoła, s. 162-163; tenże., Organizacja terytorialna, s. 188 [2]-189 [3]; Mencel, dz. cyt., s. 167; H. Gołaszewski, Dzieje części diecezji tuckiej, wileńskiej $i$ żmudzkiej $w$ Prusach Nowowschodnich po trzecim rozbiorze Polski przed powstaniem diecezji wigierskiej /1795-1800/. Studium historyczno-prawne. Praca doktorska napisana pod kierunkiem A. Petraniego na Wydziale Prawa Kanonicznego KUL, Lublin 1963, (mps Biblioteki Metropolitalnego Seminarium Duchownego w Lublinie, sygn. Rkps. 2995).

${ }^{44}$ Mencel, dz. cyt., s. 167.

${ }^{45}$ F. Stopniak, Archiwa parafialne dekanatu lubelskiego, ABMK, t. 9 s. 5-19.; Directorium Officii Divini pro Dioecesi Hetmensi et Lublinensi in Annum Christi 1798, (Jest rubrycellą bez spisu parafii, natomiast wśród dziekanów wymienia dziekana dekanatu lubelskiego).

${ }^{46}$ Słomka, dz. cyt., s. 62.

${ }^{47}$ Directorium Officii Divini pro Dioecesi Hetmensi et Lublinensi in Annum Christi Tertium post Communem 1803 
Ponadto już w 1799 r. biskup diecezji chełmskiej i lubelskiej Wojciech Skarszewski na polecenie rządu austriackiego, domagającego się dostosowania sieci dekanatów do granic cyrkułów, przystąpił do regulacji granicy przyszłej diecezji lubelskiej, której obszar w tymże roku organizowało 9 dekanatów znajdujących się w granicach 4 cyrkułów: chełmskiego (dekanat chełmski i krasnostawski), lubelskiego (dekanat lubelski, kazimierski i parczewski), józefowskiego (dekanat chodelski, urzędowski) i radzyńskiego (dekanat łukowski i stężycki).

Jednocześnie władze zaborcze narzuciły biskupowi Skarszewskiemu odłączenie od diecezji chełmskiej i lubelskiej dwóch parafii znajdujących się w cyrkule radzyńskim: parafii Siedlce położonej w dekanacie łukowskim oraz z dekanatu stężyckiego parafii Wargocin. Biskup Sakrszewski 20 czerwca 1799 r. przekazał parafie Siedlce pod zarząd administratora galicyjskiej części diecezji łuckiej w cyrkułach siedleckim i bialskim, jednocześnie pod tą samą datą delegował rządy na parafie Wargocin biskupowi krakowskiemu, zmieniając jej przynależność cyrkularną z cyrkułu radzyńskiego na cyrkuł radomski. Poza utratą dwóch parafii, 29 maja 1799 r. biskup Skarszewski, przyjął od biskupa poznańskiego zarząd nad parafią Łaskarzewską, którą włączył do dekanatu stężyckiego w cyrkule radzyńskim $^{48}$.

Po tychże zmianach kancelaria carska w Wiedniu na wniosek Gubernium Galicyjskiego w ramach ogólnej reorganizacji hierarchii kościelnej monarchii naddunajskiej, pod datą 20 sierpnia 1801 r. przedstawiła projekt kasaty diecezji tarnowskiej i chełmskiej, a ponadto plan utworzenia nowych diecezji w Kielcach i Lublinie. Zanim podjęto w sprawie diecezji lubelskiej rozmowy ze Stolicą Apostolską powołana w 1802 r. Komisja o charakterze państwowo-kościelnym na posiedzeniu przed 20 września $1802 \mathrm{r}$. wysunęła postulat przeniesienia stolicy diecezji chełmskiej i lubelskiej z Krasnegostawu do Lublina i nadania jej nazwy „lubelska". Sugerowano także włączenie do przyszłej diecezji lubelskiej tych części diecezji łuckiej, płockiej i poznańskiej, które po 1795 r. znalazły się w zaborze austriackim.

$\mathrm{Z}$ uwagi na wojny napoleońskie rokowania ze Stolicą Apostolską w tej sprawie przedłużyły się do 1805 .

W tymże roku papież Pius VII bullą Quemadmodum Romanorum Pontificum z dnia 23 września 1805 r., powołał do życia diecezję lubelską, która faktycznie zaczęła funkcjonować dopiero od 19 października 1807 r., kiedy to nastąpiło wykonanie bulli, przez delegata apostolskiego, metropolitę lwowskiego obrządku łacińskiego Kajetana Kickiego ${ }^{49}$.

${ }^{48}$ Biblioteka PAU i PAN w Krakowie, J.A. Wadowski, Dzieje diecezji chetmskiej i lubelskiej, sygn. rękop. 2366, nr mikrof. 36127, k. 20; tamże, J.A. Wadowski, Dzieje diecezji lubelskiej, k. 4244; Kumor, Ustrój i organizacja, s. 528-529.

${ }^{49}$ Biblioteka PAU i PAN w Krakowie, Erectio sedis episcopalis Lublinensis, k.1-20; Bullarii Romani continuatio ... Tomus decimus secundus continens pontificatus PII VII., Romae 1846, s. 374-381; Catalogus universi cleri ... Anno Domini 1875, Lublin 1874, s. V-XXV; Kumor, Granice metropolii, ABMK 20 (1970) s. 328 [222]; tenże, Ustrój i organizacja, s. 71; tenże, Diecezja lubelska, WDL 59 (1985) nr 5-7 s. 236-237; Archidiecezja lubelska. Historia i administracja, red. M. T. Zahajkiewicz, Lublin 2000, s. 104; L. Zalewski, Katedra i jezuici w Lublinie, cz. 1, Lublin 1947, 


\title{
THE TERRITORIAL ORGANIZATION OF THE DIOCESE OF CHELM AND LUBLIN TO 1805
}

\begin{abstract}
Summary
The following article focuses on the territorial analysis of the diocese of Chelm and Lublin from 1790 to the foundation of the diocese of Lublin by Pope Pius VII in the papal bull on 23 September 1805. The territorial structure of this diocese was formed from the two bigger and two smaller church administrative units, as in 1790 it encompassed some territory which belonged to the Metropolis of Lvov-the diocese of Chełm (three deaneries), as well as most of the Archdeanery of Lublin, which belonged to the diocese of Kraków, the Metropolis of Gniezno(apart from the deanery of Solec). From the latter diocese and metropolis, the deanery of Stężyca (from the deanery of Kielce) and the deanery of Urzędów (from the archdeanery of Zawichost) were also incorporated to the diocese of Chełm and Lublin.

Presenting the particular parts of the diocese of Chelm and Lublin created in 1790, the author also describes the years before its foundation, because the analysis of the territorial structures both the diocese of Chelm- erected in 14 the century- and the archdeanery of Lublin-created in 12th century-covers even the beginnings of the 14th century. In addition, in this article an attempt has been made to explain the diocese name controversy -created in 1790- and the titles of its first ordinary bishops: Maciej Garnysz and Wojciech Skarszewski.

The boundaries of the diocese of Chełm and Lublin underwent some changes over time due to the partitions of Poland. That is why the following article is accompanied by a few maps, which can help to illustrate each and every modification to the boundaries of the diocese of Chełm and Lublin and to show its parts along with the marked capitals of the deaneries.
\end{abstract}

Translated by Aneta Kiper

s. 143-144; J. Skarbek, W dobie rozbiorów i braku państwowości (1772-1918), w: J. Kłoczowski, L. Müllerowa, J. Skarbek, Zarys dziejów Kościoła katolickiego w Polsce, Kraków 1986, s. 187; H. Gapski, Kalendarium Kościoła Lubelskiego, w: Skarby Archidiecezji Lubelskiej, red. P. Kawałko i in., Lublin 2005, s. 309.; J. A. Wadowski, Lubelskie biskupstwo, w: Encyklopedia Kościelna podtug teologicznej encyklopedii Wetzera $i$ Weltego z licznymi jej dopetnieniami przy współpracownictwie kilkunastu duchownych $i$ świeckich osób, wyd. M. Nowodworski, t. 12, Warszawa 1879, s. 346-350; Z. Chełmicki, Lubelskie bpstwo, w: Podręczna Encyklopedia Kościelna, oprac. S. Gall i in., red. Z. Chełmicki, t. XXV-XXVI, Warszawa 1911, s. 4-5; P. Aleksandrowicz, Diecezja Siedlecka czyli Podlaska. W 150 rocznicę erekcji (1818 - 1968). Przyczynki i materiaty do dziejów Diecezji Siedleckiej czyli Podlaskiej, Siedlce 1971, s. 74; Zahajkiewicz, Diecezja, jej granice, s. 37-38; K. Turowski, Diecezja lubelska, „Przewodnik Katolicki” 58 (1968) s. 12. 